\title{
DANÇANDO PARA ALÉM DAS REGRAS
}

\author{
DANZANDO MÁS ALLÁ DE LAS REGLAS
}

DANCING BEYOUND THE RULES

\author{
Daniely Peinado dos Santos ${ }^{1}$
}

\begin{abstract}
RESUMO
Apresenta algumas considerações sobre o uso do jogo como mediador de processos criativos em dança, a partir de proposta desenvolvida em escola pública de Ensino Fundamental em Manaus. A escrita descreve as ações tomadas, tecidas com outras experiências de ensino da dança, se completando no encontro com os alunos e os processos criativos surgidos a partir dessas relações. Percebendo o potencial motivador que o jogo estabelece na criação em dança na escola, são desvelados processos onde puderam ser construídos novas atitudes e valores, proporcionando aos alunos perceberem-se criadores e partícipes, mais sensíveis ao mundo que os cerca.
\end{abstract}

PALAVRAS-CHAVE: dança, educação, jogo, processos criativos

\section{RESUMEN}

Presenta algunas consideraciones sobre el uso del juego como mediador de processos creativos en danza, a partir de propuesta desarrollada en escuela pública de Enseñanza Fundamental en Manaus. La escritura describe las acciones tomadas, tejidas con otras experiencias de enseñanza de la danza, completándose en el encuentro con los alumnos y los procesos creativos surgidos a partir de esas relaciones. Percibiendo el potencial motivador que el juego establece en la creación en danza en la escuela, se desvelan procesos donde se pudieron construir nuevas actitudes y valores, proporcionando a los alumnos se perciban creadores y partícipes, más sensibles al mundo que los rodea.

PALABRAS CLAVE: danza, educación, juego, procesos creativos

\begin{abstract}
The text presents some considerations about the use of the game as mediator of creative processes in dance, based on a proposal developed in a public elementary school in Manaus. The writing describes the actions taken, woven with other experiences of teaching dance, completing in the meeting with the students and the creative processes arising from these relationships. Realizing the motivational potential that the game establishes in dance creation at school, processes are unveiled where new attitudes and values could be built, allowing students to perceive creators and participants, more sensitive to the world around them.
\end{abstract}

KEYWORDS: dance, education, game, creative processes

\footnotetext{
${ }^{1}$ Atriz. Professora. danielypeinado@gmail.com
} 
A experiência aqui descrita reflete o processo de pesquisa desenvolvido durante finalização da graduação em Dança em 2009, a mesma consistiu na investigação de processos de criação artística na relação dança e jogo, uma proposta educativa desenvolvida em instituição de ensino regular da rede municipal de Manaus. Para tal, buscou-se identificar as concepções de jogo no contexto escolar pesquisado, analisar possíveis relações entre jogo lúdico e jogo dramático na dança e suas implicações nos processos criativos enquanto contribuição no campo da dança-educação.

As aulas consistiram de oficinas que aconteciam pela manhã ${ }^{2}$ com abordagem teórico-prática de conteúdos específicos da dança através de jogos lúdicos, organizadas a partir da proposta triangular de Ana Mae Barbosa: apreciação, prática artística e contextualização, acrescidas de um círculo de discussão. Desenvolvida durante 5 meses, contou com a participação de 11 (onze) alunos do $6^{\circ}$ e $7^{\circ}$ ano do Ensino Fundamental, gerando um processo de sensibilização, no qual os alunos vivenciaram experiências estéticas e foram estimulados e motivados pelo jogo para criarem células coreográficas, fato que permitiu um real envolvimento dos alunos, a partir de uma compreensão do processo criativo em dança.

Garantir um desenvolvimento completo e integrado à criança é uma desejo muito recorrente de pais e professores, posto que é grande a procura de atividades destinadas a idade escolar, além deste também ser um ideal da educação, conforme registrado nos PCN (BRASIL, 1997). Sabemos que existem projetos pedagógicos que dão conta deste ideal, principalmente em escolas particulares, e que nas escolas públicas há interesse e necessidade de atividades que possam contemplá-lo. É verdade também, que em algumas escolas públicas isso já é possível, mas não era o caso da Escola escolhida por mim como campo da pesquisa.

Quando na minha chegada, em uma conversa com o pedagogo que assistia à mesma na época, ele relatou que a turma lotaria, pois qualquer coisa que aparecesse na escola fora de uma aula tradicional seria encarado como diversão. Os alunos com muita

\footnotetext{
2 Vale ressaltar que manteve-se contato com as turmas dos alunos envolvidos nas aulas de artes (horário regular), fato positivo que proporcionou extensão da proposta a outras turmas e uma melhor perspectiva para esta análise.
} 
energia para gastar iriam aderir à proposta e que a escola tinha interesse em atividades extracurriculares.

Analisando sua fala, embora a aceitação da proposta tenha sido um fato positivo, a forma de olhar para a dança como extracurricular não condiz com o propósito da arte na educação: "o papel da arte e da dança nas escolas seria justamente o de possibilitar uma transformação contínua da existência, o de mudar referências, o de proporcionar novos e múltiplos olhares sobre o mundo" (STRAZZACAPPA, 2006, p. 115). E o "sim” da Escola, me fez perceber que o momento era de construção de sentidos para os funcionários, professores, alunos. Sobre o outro aspecto de seu depoimento: em parte foi verdade. Não apenas na quantidade de alunos na turma (pela manhã), mas no envolvimento dos alunos (em geral) com os conteúdos das aulas, que em pouco tempo se tornou efetivo. Mas antes de seguir para o encontro com os alunos, falemos do jogo.

Ao pensar em jogo enquanto meio para o conhecimento, cabe apontar um recorte sobre o sentido dado a ele enquanto experiência para futuras situações, pois durante a adaptação que ocorre na relação do sujeito e o objeto de conhecimento, dentre outros mecanismos, o homem faz uso do jogo para domínio de situações diversas. "Para Piaget [...] o jogo é assimilação da experiência nova - como a resposta aprendida para os behavioristas ou o domínio do meio para Freud" (PIAGET apud COURTNEY, 2003, p. 270).

O fato é que, ao longo da existência humana - especialmente na infância e na adolescência - o jogo pelo jogo se faz presente e podemos facilmente perceber a dedicação que lhe é destinada. Esta aliás, é uma das características atribuídas ao jogo: o isolamento criado pelo intervalo da vida comum, que demanda que ele aconteça "dentro de certos limites de tempo e de espaço" (HUIZINGA, 2000, p. 11). Basta olhar o pátio de uma escola no intervalo para encontrar uma infinidade de jogos que os alunos imergem para se divertir.

Quando questionados no entanto, podemos observar que a diversidade e frequência não correspondem à consciência de possibilidades dos jogos. Jogos esportivos e videogames estão no topo da lista dos mais citados, conforme falas dos alunos: 
Futebol, PSP3, queimada, corrida de carro, vôlei... (J.S.)

Futebol, basquete. (B.J.)

Futsal. (B.W.)

Vôlei. (A.S.)

Ao ser percebida a limitação ao esporte e aos jogos virtuais mencionei um jogo bem simples: o par ou impar, foi então que eles lembraram:

É! De disputa. É jogo. (J.F.)

Intuitivamente, o sentido mais comum dado ao jogo pelas crianças e adolescentes se refere à diversão. Através de regras e convenções próprias eles estabelecem à sua maneira, os procedimentos para jogar e se divertir. Jogos tradicionais e espontâneos simplesmente surgem sem a preocupação de momento certo ou regras que não possam ser recombinadas.

Huizinga (2000) nos fala sobre esse gosto das crianças pelo jogo e que é exatamente por ser voluntário que o jogar instaura uma liberdade. Este clima de liberdade permite-nos uma aproximação com o momento de criação, um momento em que precisamos ser livres para experimentar e sentir a alegria contagiante das crianças, inteiramente absorvidas em seu fazer (OSTROWER, 1999).

Levando-se em conta essa abertura para a combinação de novas regras e criação de novos jogos é que me propus a jogar com eles e gradativamente introduzir conteúdos da dança. Quando foi divulgado que aconteceriam aulas de dança na escola, muitos alunos se interessaram, porém no dia marcado só apareceram 7 (sete) alunas cheias de expectativas, as principais perguntas:

Qual vai ser o estilo de dança? (N.V.)

Vai ter apresentação? (K.O.)

A dança tem a ver com teatro? Gosto de teatro. (B.W.)

Conversamos um pouco e foi explicado como seriam as aulas, que não "fecharíamos" em um "estilo" específico, mas que iríamos ter contato com o maior número possível de "estilos" e produções de dança, falei que se tratava de uma pesquisa

\footnotetext{
${ }^{3}$ Em referência ao console de videogame portátil - Playstation Portable.
} 
e comentei sucintamente sobre ela. Ainda sem entender a proposta em sua totalidade experimentamos (no pátio) o primeiro jogo: fazer um movimento que representasse sua "marca" pessoal. Para elas se sentirem à vontade foi feito um aquecimento e depois o jogo, que depois virou um experimento com movimentos que juntos faziam uma dança. Toda a aula foi envolvida por risos. Além da vergonha, elas se divertiram com o jogo.

Fizemos algumas aulas só com elas. Ficamos na esperança de que os meninos comparecessem às aulas até que novamente perguntei sobre eles, elas responderam:

Os meninos não! Eles são bagunceiros! (N.V.)

O único que talvez venha é o Junior. (K.O.)

As meninas não se percebiam fechadas a relações com os meninos. A principal justificativa era que eles não se adequariam as aulas e nos atrapalhariam. Esse pensamento revela uma questão muito presente em relação à divisão de atividades por gênero e porque um grupo se encontra melhor em determinadas atividades.

Maturana (2004) aponta um caminho possível para a mudança de padrões culturais: uma mudança no emocionar, pois a emoção define a ação. O autor coloca que: "É a emoção a partir da qual se faz ou se recebe um certo fazer que o transforma numa ou noutra ação, ou que o qualifica como um comportamento dessa ou daquela classe" (MATURANA, 2004, p. 10).

Assim, tentei explicar como seria interessante se os meninos participassem com elas do grupo, aliás, notei que alguns dias uns meninos rondavam a sala enquanto fazíamos as aulas. A conversa pareceu surtir efeito, pois na aula seguinte elas trouxeram alguns colegas que passaram a integrar o grupo.

Com um número significativo, desenvolvemos nossas aulas considerando o jogo como premissa para a criação em dança. O fato porém, do grupo variar em quantidade, fez surgir um problema relacionado ao espaço físico das aulas: a sala.

Nas primeiras semanas encaramos como jogo procurar um espaço para as aulas. A quadra foi apontada pelas alunas, mas o Diretor informou que ela era ocupada integralmente pelas aulas de educação física. A sala de vídeo, indicação do pedagogo, também não poderia ser utilizada por questões físicas: para chegar até ela tínhamos que passar por dentro da biblioteca, o que atrapalharia os frequentadores. A opção que nos 
restou: uma sala de apoio, já ocupada pelos seguranças da escola, algumas carteiras, entre outros objetos. Ficamos lá. Esta pequena sala, muito acolhedora, às vezes não comportava nossos jogos. Era então quando saíamos para o pátio ocupando outros espaços.

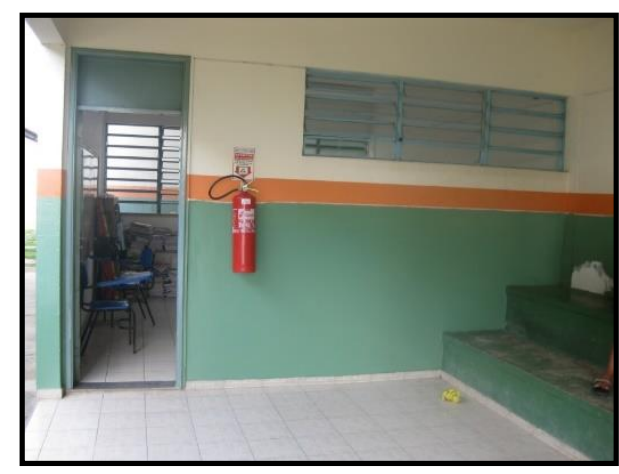

Foto 1: Sala de apoio utilizada nas aulas.

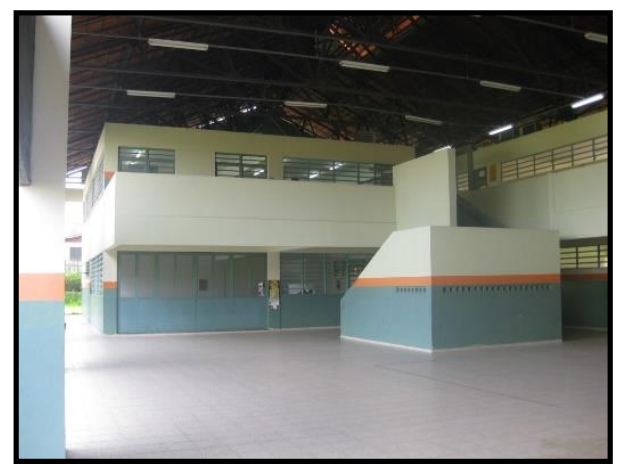

Foto 2: Pátio interno da escola.

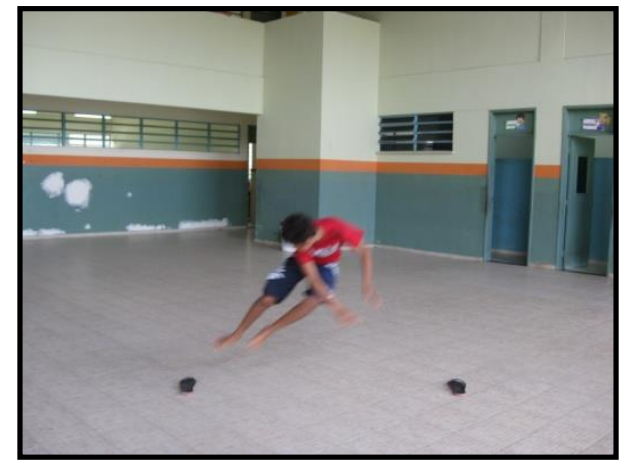

Foto 3: Momento da aula no pátio interno.

Sobre a questão de ocupar outros espaços, vale à pena ressaltar que a pesquisa não se restringiu ao grupo, mas alcançou suas turmas. Em uma conversa com a Professora de Artes dos alunos envolvidos nos encontramos permeadas pela Dança: ela estava prestes a iniciar o conteúdo do bimestre, dança. Dela veio o convite para acompanhar as aulas estendendo a proposta com os jogos às aulas de artes. Comecei a ir para a escola pela manhã, com o grupo, e pela tarde, com as turmas. 


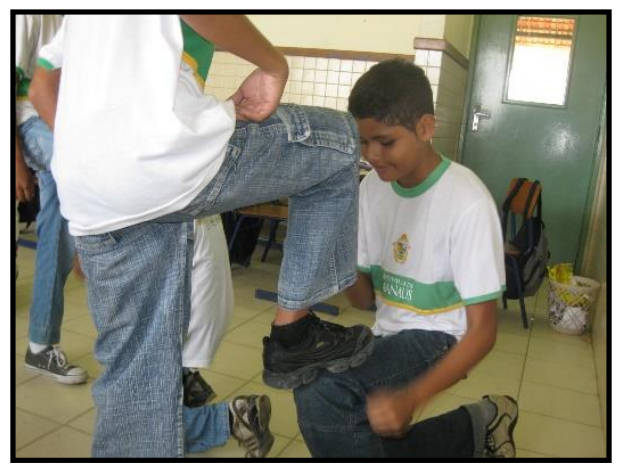

Foto 4: Jogo na aula de artes.

A atitude da professora revela uma postura interessante frente à polivalência "imposta" pelo sistema educacional ao professor de arte. Ela, que tem formação em Educação Artística com habilitação em Música e é professora de violão, revela a origem dos meios alternativos de solucionar suas limitações acerca das especificidades (expressões artísticas) exigidas: Um curso de formação continuada para professores numa instituição privada, nas palavras dela:

Não fiz sempre assim. Esse curso que eu "tô" fazendo me abriu muito as ideias. Antes eu não pensava assim: Não é só teoria. Nem só prática. São os dois. No momento que eu tinha decidido por essa estrutura, você estava aqui. Então aproveitei (Professora de Artes).

Assim, os jogos e a dança tomaram conta dos corredores, das salas 'regulares', das escadas, da quadra, da escola.

Buscando referências no historicidade da dança na escola, encontrei na ideia de dança-educação um caminho para pensar uma proposta na qual o aluno pode reestruturar suas percepções através da dança e do movimento, transformando-as em uma visão de mundo (BARRETO, 2005). Com o objetivo distante da formação de bailarinos, essa ideia é pertinente a proposta com os jogos pois encontra neles o "espaço" que proporciona segurança e liberdade aos jogadores para manifestarem suas ideias e emoções através do movimento.

Para que isso ocorra, no entanto, é necessário que eles de fato entendam como criar em dança, mais que simplesmente movimentar-se segundo regras convencionadas. Daí o embasamento na proposta triangular de Ana Mae Barbosa: proporcionar ver, fazer e contextualizar arte, no caso, dança. A abrangência da proposta proporciona espaço 
para sensibilização e consequentemente para a construção de sentidos (BARBOSA, 2005).

Com base nesses estudos, as aulas eram organizadas em três momentos estruturados na sequência que melhor se adequasse ao tema do dia. Portanto, no geral:

Contextualização: $\mathrm{Ou}$ aquecimento, neste era apresentado o que seria trabalhado no dia. Aqui se dava a preparação corporal para inteirar-se da proposta para o movimento. Por vezes, jogos introdutórios faziam esse papel, seguidos de uma discussão acerca do tema. Foram usados vídeos, fotos, imagens, jogos e textos para visualização dos conteúdos.

Fazer artístico: Era o momento em que experimentávamos o movimento baseado na proposta, dividido em duas partes: 1) improvisação, onde jogávamos, criávamos. Dependendo do nível de entendimento ele podia ser breve ou prolongado; 2) fragmentos coreográficos, eram os experimentos propriamente ditos, estes tinham um acabamento em comparação ao anterior, aqui tentávamos utilizar os movimentos surgidos a partir dos jogos na dança.

Apreciação: Às vezes acontecia no próprio momento da criação. Quando a criação era em grupo, tínhamos os jogadores e os outros sentavam e assistiam (plateia), ou do mesmo modo se individual. Também foram considerados neste, vídeos e fotos.

Esta proposta metodológica proporcionou em muitos momentos o que Wilson (2005) chama de uma lição de arte ideal, pois enquanto estavam "fazendo arte", os alunos também conheciam grupos e trabalhos artísticos importantes e algumas lições que podiam ser ensinadas através delas.

Uma alteração no entanto, teve de ser feita após tomar conhecimento dos alunos na primeira aula, vi a necessidade de criar mais um momento: o quarto, aliado ao ver que não consistia na simples socialização dos "produtos", mas numa troca acrescida de comentários e questionamentos no círculo de discussão. 


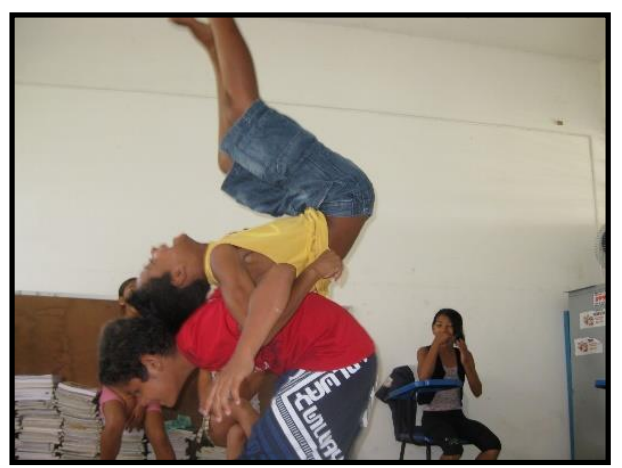

Foto 5: Momento de fazer artístico - Contato-improvisação.

No planejamento das oficinas essa estrutura funcionou como base para construir sentidos junto aos alunos para que as mesmas fossem mutuamente significativas, "a vida humana não é apenas vida (física) mas existência, ou seja, comporta um sentido" (DUARTE JÚNIOR, 2001, p. 20).

Dessa forma, os alunos conscientes da pesquisa, puderam não só experimentar o processo de criação em dança mediado pelos jogos, mas também entendê-lo. A consciência de ser parte integrante e colaboradora da pesquisa propiciou além de uma maior entrega, familiaridade e interesse com os questionamentos, com o registro audiovisual e com as convidados ${ }^{4}$ que levei às aulas.

A estruturação nos moldes citados não só proporcionou um melhor aproveitamento dos momentos das aulas na coleta de informações, como também dos colaboradores que motivados pelo jogo participavam integralmente do processo, demonstrando satisfação. Quando questionados no final de uma aula sobre o processo do dia:

Foi bom! Parece que as meninas estão animadas e fica bom. (N.V.)

Foi maravilhoso! Ficou interessante [o produto final], o grupo está grande... (A.S.)

Foi interessante. Ajuda a desenvolver a dança. (G.K.)

A definição da estrutura também facilitou a ordenação dos conteúdos intitulados: dança e jogo; conscientização corporal: articulação, trajetórias, linhas e formas; qualidades de movimento; flexibilidade; contato improvisação; música e dança; técnicas corporais na dança (Dança Clássica) e fora dela (Kung Fu).

\footnotetext{
${ }^{4}$ Levei dois professores de técnicas corporais distintas: balé clássico e kung-fu.
} 
Barreto (2005) nos aponta que nas aulas de dança além dos conteúdos específicos, outros sobre a dança e de sensibilização são demandados, assim, as aulas não só apresentaram significativamente os tópicos listados acima como também proporcionaram tomadas de consciência de si e das possibilidades enquanto ser criativo na pesquisa pessoal.

Os experimentos de dança da forma como eram conduzidos já eram o próprio jogo. Quando no aquecimento eram considerados introdutórios, quando no desenvolvimento da aula propriamente dita, estabeleciam de que forma tínhamos que nos movimentar num ambiente prazeroso e envolvente.

Estranhamentos, busca por soluções, superações, tudo isso de alguma forma os fez conhecer-se e ao seu próprio corpo, tendo em vista que a primeira atitude do professor a ser tomada segundo Vianna "é dar um corpo ao aluno" (VIANNA, 1990, p. 62). Nesse sentido de construção de movimentos, o jogo participou na dança, tal como Ryngaert afirma que,

o engajamento corporal varia de acordo com os participantes e as improvisações, mas apóia-se também na imagem de pessoas "de bem com seu corpo", isto é, prontas para o contato e a troca. $\mathrm{Na}$ falta de uma base técnica ou de aprendizagem de uma gramática estrita, esses jogos do corpo pertencem a uma zona um pouco "selvagem", na qual se espera que os participantes se lancem jogando pelo/com seu corpo e que criem em função dele” (RYNGAERT, 2009, p. 71).

Dessa forma, o jogo na dança pôde abrir caminhos para o despertar de uma dança gradativamente construída a partir de ideias de movimentos e não de estilos específicos.

Certo dia quando ia subindo as escadas para a sala de aula à tarde, ouvi um: "Professora ajuda a gente?" Era um grupo de meninos ensaiando um trabalho de dança:

É que a gente fez e a professora [de Artes] disse que 'tava' muito violento. (A.1)

Pedi para ver e eles fizeram. Realmente, a violência estava presente, e ficava confusa a relação com o tema do trabalho: qualidades de movimento. Quando questionados sobre a relação com a atividade os alunos responderam:

Nenhuma... (risos). 
Fui mediando as etapas de criação do trabalho. Eles já tinham compreendido o conteúdo só precisavam de estímulos para ajustar os movimentos. Na transcrição do diálogo:

Eu: Vamos lá! Olhem para mim... (executo a ideia deles parte a parte. Começo escovando os dentes.) Este é o quê?

Aluno 2: Vibratório!

Eu: Ah! E esse? (Varrendo.)

Aluno 2: Pendular!

Eu: Então vocês já tem a metade.

Alunos: É! (Comemorando.)

Eu: Faltam qual?

Aluno 2: O contínuo e o... percutido.

Aluno 3: Assim... (Faz movimentos articulados e rápidos.)

Eu: Isso! Qual é esse?

Aluno 3: Percutido. Falta só o contínuo.

Eu: A respiração. Vocês podem ampliá-la.

Aluno 4: $O$ andar também 'né?

Eu: Sim.

(Fui ver outros grupos. Depois voltei.)

Eu: Posso ver como ficou?

Alunos: (Empolgados) Pode. (Eles fazem.)

Citando este trabalho, podemos observar que em pouco menos de um mês e numa frequência de duas aulas por semana (aulas de artes), o envolvimento dos alunos era tamanho que a ideia comum de que meninos não dançavam, já não fazia parte dos comentários nem das práticas nas aulas. Todos participavam e incentivavam uns aos outros. Nas aulas inclusive, eles manifestavam interesse em participar do grupo pela manhã e lá mesmo justificavam o motivo pelo qual não poderiam. O mesmo trecho remete a ideia de zona de desenvolvimento proximal de Vygotsky (1989), onde o professor (mediador), experiente, ajuda o aluno a construir conhecimento a partir do nível de desenvolvimento real.

Com o grupo pela manhã acontecia do mesmo modo. Na medida em que o tempo passava, a relação dança e jogo ficava cada vez mais próxima. Em um exercício semelhante as alunas criaram uma sequência experimental baseada em jogos conhecidos. Como de costume em aulas exaustivas, houve uma sessão de relaxamento. Coloquei uma música já conhecida e pedi que deitassem. Algumas assim fizeram, mas outras que estavam aglomeradas num canto da sala chamaram atenção pelo burburinho. Elas estavam montando uma estrela com as mãos em cima do corpo de uma aluna. 
Nos dois momentos citados acima, confirmamos o quanto o jogo já era presente no cotidiano dos alunos. O que aconteceu em muitos casos foi a apropriação da pesquisadora e um direcionamento para a dança, fato que estreitou ainda mais essa relação.

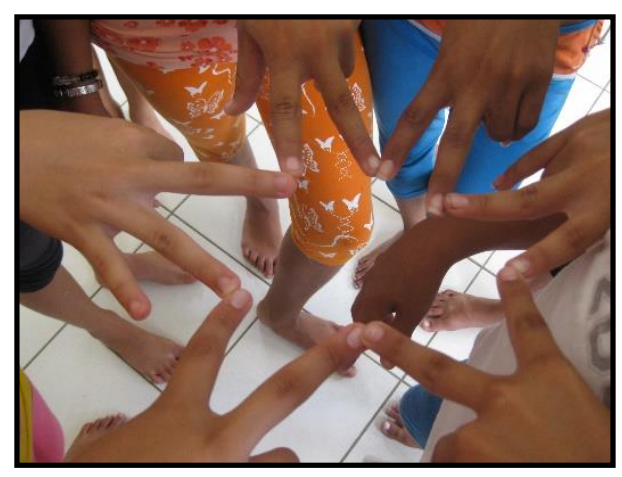

Foto 6: Reprodução da brincadeira espontânea estrela.

Numa outra aula de artes, a qual foram exibidos vídeos (filmes e espetáculos de dança) foi comprovado o quanto eles já tinham parâmetros para inclusive falar sobre dança. Foi solicitado que eles escrevessem sobre o que viram em um relatório. As percepções foram das mais variadas. Alguns se apoiaram em pontos em comum entre os vídeos e foram mais diretos: o cenário, as roupas, a maquiagem. Outros localizaram questões discutidas em sala de aula:

Eu percebo pessoas dançando. E com essa dança alguns movimentos foram praticados, cujo um deles foi o movimento pendular. (W.M.)

Houve ainda outros mais narrativos e detalhistas:

Vejo muitos olhos brilhando, e surge um gato e se assusta com a luz, e retorna à escuridão, depois vai saindo devagar vários gatos de diferentes cores e raças. Eles começam a dançar, a dança deles parece com movimentos de gatos, e começam a cantar, a maquiagem ajudou com que eles ficassem muito parecidos com gatos de verdade [...] não percebi o movimento pendular, esse filme se trata de um musical com dança e canto. (A.C.)

Esses relatos, surgidos a partir do momento de apreciação demonstram que a proposta metodológica triangular contempla o envolvimento dos alunos, pois ele promove condições para que eles se apropriem dos conteúdos. A contextualização anterior ao vídeo, os momentos de exercícios práticos, e por fim, a apreciação, 
construíram uma unidade de ideias proporcionando outro "olhar" dos alunos para com a dança.

Nas aulas, as referências anteriores os deixavam cada vez mais envolvidos, a exemplo de um dia na saída da aula, que fiquei aguardando a professora de Artes mais do que de costume, até ela finalmente descer e comentar sorrindo:

Nunca fui tão sugada em toda minha vida.

Os alunos perguntavam sobre a apresentação de dança que aconteceria numa grande programação envolvendo música, poesia e dança na escola. Queriam saber quando seria, quem estaria envolvido, se eles podiam participar, se podiam acrescentar detalhes no relatório além do que ela havia solicitado, várias perguntas que bombardearam a saída da professora e a atrasara. Ao que ela comenta:

Acho que o processo foi muito produtivo. Não penso no resultado amanhã, mas o quanto nesse processo, os alunos puderam aproveitar desse período que você esteve com eles.

Gradativamente os resultados desse processo iam surgindo. Primeiro nas aulas, depois nos alunos, depois na escola. O fato de o evento estar próximo mobilizou os professores, outros funcionários e os alunos das outras turmas. Quando perceberam que haveria algo nos abordavam. Essas atitudes apontam para os já perceptíveis resultados do processo desenvolvido na escola. A repercussão que os preparativos do evento provocaram nos alunos e funcionários demonstrou a disposição para o envolvimento no trabalho. As questões partiam não só da curiosidade como do apoio para participação e colaboração no evento.

Todas estas situações provocadas pelos processos criativos confirmam a ideia crescentemente reconhecida da importância da criatividade em todos os campos humanos, no sentido de desenvolver as competências comportamentais, perceptuais, afetivas e simbólicas desejáveis em qualquer área profissional (ALENCAR; FLEITH, 2003). Apenas para citar: iniciativa, flexibilidade, tolerância, autoconfiança e cooperação são alguns dos valores que podem ser discutidos e compreendidos na prática durante o processo criativo. 
Entre outras atitudes, indicadores de outros saberes tornavam-se aparentes: a percepção da música, por exemplo, observável nos ensaios do trabalho final com o grupo, foi diferente das primeiras, quando era considerada um simples acompanhamento para a dança. Na elaboração da sequência, eles não se preocupavam apenas se a música era agitada, se a letra era bonita. Agora tinham outros requisitos como compor a cena, combinar com a ideia da coreografia. Mudanças possíveis a partir do processo de sensibilização desenvolvido na escola, o qual mobilizou internamente os alunos a transformarem suas ações, sentimentos e percepções em relação à dança.

A própria ideia de jogo e de dança, que antes se limitavam aos esportes e videogames e danças populares e folclóricas, respectivamente. Depois de um tempo das aulas, já citavam dança contemporânea, jazz, balé moderno, antes nem lembradas, e generalizavam as que conheciam: “danças populares” ao invés de forró, axé, funk. Informação que revela a consciência (ainda que superficial) da dança como produto cultural e suas relações formais (BRASIL, 1997).

Sobre o jogo em específico, um dia quando comentávamos uma apresentação ${ }^{5}$ que assistimos juntos na escola, comecei a indagá-los:

Eu: O que vocês acharam? Os movimentos eram óbvios? Teve algum que surpreendeu vocês? J. S.: O do tiro' ${ }^{6}$.

Eu: Isso é dança para vocês?

Todos: Sim.

Eu: Então se vocês fossem criar uma dança e ainda não tivessem visto a apresentação vocês colocariam esse movimento, por exemplo, na dança?

A.S.: Não. Acho que não.

Neste diálogo podemos perceber as mudanças de referências sobre dança. O fato de os alunos que dançaram terem apresentado em sua sequência um movimento fora do repertório deles e eles terem conseguido entender a proposta, ampliou o registro visual sobre dança. Num outro dia retomando esta discussão, quando havia explicado que alguns jogos estavam mais relacionados ao brincar, à diversão e outros se relacionavam à representação de suas ideias em movimentos de dança, eles demonstraram ter compreendido essas colocações através de referências práticas:

\footnotetext{
${ }^{5}$ A apresentação fazia parte da campanha de desarmamento promovida pela escola.

${ }^{6}$ Os alunos do $9^{\circ}$ ano apresentaram uma coreografia de hip hop, na qual um aluno simulava receber vários tiros.
} 
Eu: Os jogos que fizemos nas aulas no começo são quais?

Todos: De brincar.

Eu: E quando os meninos, no hip hop, colocaram aqueles tiros na coreografia?

Todos: Representação.

No trabalho final esse entendimento fez toda uma diferença, pois a partir do tema escolhido, eles mesmos solucionavam as coreografias.

Professora, eu e a B. vamos fazer o giro e terminar assim. (Mostra a execução do mesmo movimento em direções opostas) (K.O.)

Tive uma ideia: Essa hora a gente pode girar, passando por eles e sair. (A.S.)

As aulas com os jogos proporcionaram aos alunos experiência na dança, facilitando o reencontro nos processos criativos com situações já vivenciadas (COURTNEY, 2003). Todas as situações mencionadas anteriormente nos fazem reconhecer o valor do jogo e sua aplicabilidade em sala de aula, e melhor, na dança.

Rooyackers (2003) se lançou à proposta de combinar o jogo e a dança de maneira a promover a espontaneidade e a expressão do aluno, o qual aprende se divertindo:

None of these dance games involve memorizing standard steps. The games challenge players to improve and experiment with unusual movements. Players explore the world around them and come up with creative ways to express emotions and ideas through movement. The dance games also provide dozens of opportunities for players to create and develop their own choreography 7 (p. 1).

Podemos perceber que esta proposta se aproxima do propósito da dançaeducação quando menciona que mais importante que os passos difíceis, ou a técnica, é a possibilidade de os alunos criarem sua própria dança no uso de informações do meio.

Em uma aula com jogos, podemos percebê-los surpresos com suas criações:

Eu sabia que a gente ia dançar, mas não sabia que ia ficar assim. (Em relação ao uso dos movimentos surgidos num jogo para a coreografia.) (A.S.)

Achei legal! (K.O.)

Foi diferente! Foi legal porque ajudou a... como é que se fala... a desenvolver (sobre eles terem algo como guia) para elaborar o movimento. Lá na igreja a gente cria mas é diferente. (T.S.)

Eu: Como é?

Tem uma coordenadora, é ela que cria. Às vezes ela pede pra gente criar, mas só escolhe os... (T.S.)

Eu: Os movimentos que ela acha interessante.

Isso. (T.S.)

\footnotetext{
7 Nenhum desses jogos em dança envolve memorização de passos complexos. Os jogos desafiam os jogadores a desenvolver e experimentar movimentos diferentes. Os jogadores exploram o meio ao seu redor e surgem maneiras criativas de expressar emoções e ideias através do movimento. Os jogos em dança também promovem várias oportunidades para os jogadores de criar e desenvolver suas próprias coreografias (tradução da autora).
} 
Nesse dia, em especial, usamos todos os movimentos propositadamente. Os ajudei na elaboração para transformar aqueles movimentos em dança. Num outro dia os deixei livres para solucionar as junções de fragmentos coreográficos, e eles sozinhos perceberam na prática que nem todos os movimentos entram para o produto final, mas precisam ser experimentados:

Tive uma ideia: E se esse aqui, a gente fizesse assim? (mostra, alterando o movimento original.) (A.S.)

Professora, não tá dando certo o [movimento] das meninas, a gente pode mudar e colocar o delas (sugerindo alteração). (Y.C.)

Não diferente dos jogos tradicionais, os jogos em dança além do envolvimento pelo prazer que criar um trabalho pessoal propicia, proporcionam aos seus jogadores melhora no rendimento físico, pois dançar necessita de trabalhos de força, de equilíbrio, de agilidade, de precisão, de flexibilidade, além de exigir um tempo de resposta relativamente rápido instigando-os a tomar consciência de seu corpo e de como movê-lo criativamente.

A composição do trabalho final se deu através da divisão das aulas em ensaios e laboratórios criativos. A partir da definição do tema: amor, iniciamos os ensaios. Durante o processo de criação do trabalho conversei com os alunos sobre as possibilidades de dançarmos a ideia discutida sem tratá-la de forma direta, ilustrativa. Eles receberam essa informação de forma interessante pois logo após a execução de minha proposta para a segunda coreografia eles ficaram entusiasmados para aprendêla.

A primeira sequência coreográfica foi aproveitada de um trabalho criado pelos alunos, o qual sofreu algumas adaptações. Após eles aprenderem a sequência, eles comentavam preocupados o que os outros poderiam achar do nosso trabalho, mas a percepção de uma ideia "dançada" tinha outro sentido agora.

Se a dramaturgia é uma espécie de nexo que ata ou dá coerência ao fluxo incessante de informações entre o corpo e o ambiente; o modo como ela se organiza em tempo e espaço é também o modo como as imagens do corpo se constroem no trânsito entre o dentro (imagens que não se vê, imagens-pensamentos) e o fora (imagens implementadas em ações) do corpo organizando-se como processos latentes de comunicação (GREINER, 2008, p. 73). 
Esse referencial pôde ser utilizado na criação da última coreografia, a qual foi elaborada coletivamente seguindo a ideia de explorar movimentos não ilustrativos. Assim, foi finalizada a criação de movimentos e num sentimento que era comum a todos os envolvidos comemoramos o fechamento do trabalho.

V.J., aluno que não pôde prosseguir dançando por uma fratura no braço, comentou:

Professora tô emocionado! Eu sou o primeiro a aplaudir.

Fizemos um ensaio completo e ele, mesmo com o braço engessado, dançou alguns passos da sequência coreográfica ao meu lado. Esse foi outro ponto positivo resultante dos jogos em dança: o encontro com valores sociais como a cooperação, confiança e respeito além da autoconfiança (ROOYACKERS, 2003). Jogos em duplas, em grupos, ou mesmo os individuais foram permeados pelas trocas de experiências, seja pela decisão de como solucioná-lo ou no momento em que foram assistidos.

Num outro momento, relembrando o processo de aulas, uma com tema "contato improvisação", durante o círculo de discussão foi proposto que a análise seguisse o jogo: Se não tivéssemos... não teríamos conseguido fazer o exercício contato improvisação. Ao que surgiu:

Equilíbrio, para se manter. (Y.C.)

Confiança, no outro. (R.J.)

Força, para segurar o outro. (A.S.)

Flexibilidade, para explorar. (V.J.)

Criatividade, para experimentar. (J.K.)

Coragem, para fazer. (K.O.)

Desenvolvimento, nas aulas anteriores. (G.K.)

Nervosismo, para a superação. (N.R.)

Espaço, para fazermos nele. (T.S.)

Preocupações consigo, com o outro, com o espaço, demonstram o surgimento de novos valores sociais alcançados naturalmente, sem imposição. As aulas gradativamente construíram a dança de forma a tornar objetivas as manifestações subjetivas. Dentro de uma estrutura bem semelhante à utilizada, a organização dessas sessões é proposta por Viola Spolin (2006) e Paul Rooyackers (2003) de uma forma a estabelecer naturalmente junto com o teatro, e a dança, espaços para a socialização dos trabalhos criados, além de um momento de discussão onde serão colocadas as 
impressões e as experiências, espaços esses onde serão construídos os significados pessoais, tão importantes para ganhar um sentido para os jogadores.

Apenas um ensino criador, que favoreça a integração entre a aprendizagem racional e estética dos alunos, poderá contribuir para o exercício conjunto complementar da razão e do sonho, no qual conhecer é também maravilhar-se, divertir-se, brincar com o desconhecido, arriscar hipóteses ousadas, trabalhar duro, esforçar-se e alegrar-se com descobertas (BRASIL, 1997, p. $35)$.

No último círculo de discussão, após nossa apresentação, propus uma conversa sobre o nosso processo analisando nossos ganhos. Alguns comentários foram sobre a coragem de apresentar em público uma produção que poderia ser considerada sua, outras sobre as amizades construídas e sua importância para os avanços do grupo, outras ainda em relação ao espaço que eles enquanto colaboradores cultivaram quando contribuíam com apoio e proposições para o trabalho final. Seus comentários sobre a avaliação do processo, possível pelo real envolvimento com ênfase nele, pois cada momento foi vivenciado num presente que não confundia processo com resultado (MATURANA, 2004), revelam que seus crescimentos estão no campo das relações uma vez que as aulas foram/são lembradas numa dimensão que transcende a obra.

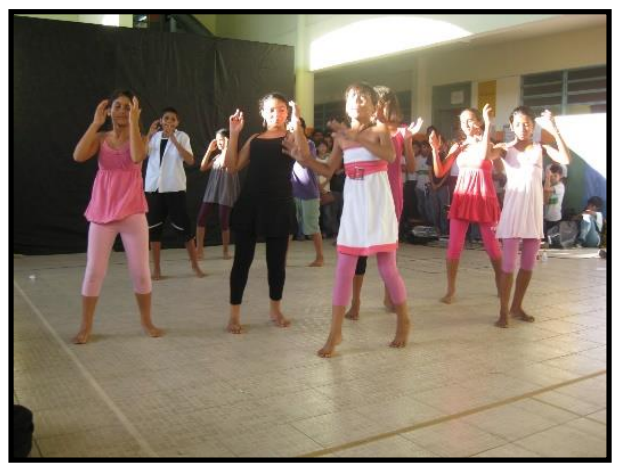

Foto 7: Momento inicial da apresentação da coreografia.

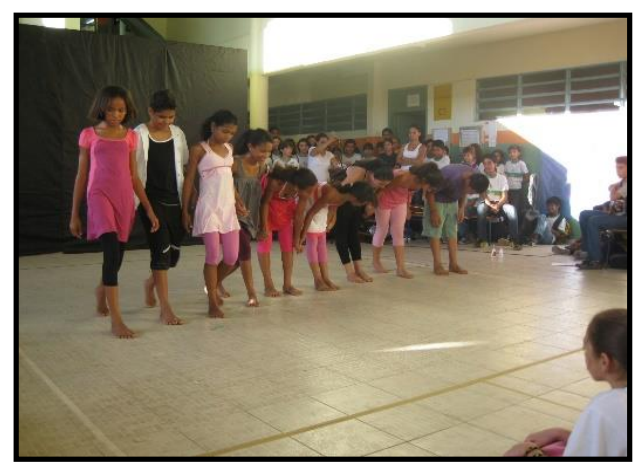

Foto 8: Momento final da apresentação da coreografia.

A arte pode ser um caminho possível para contribuir com a educação de outro olhar para o mundo e assim permitir aos alunos exercitarem seu senso crítico e criativo. Distante da preocupação de formar artistas a proposta apoiada na ideia de arteeducação, proporcionou a construção de significados através de trabalhos artísticos e permitiu aos alunos jogarem com informações que ultrapassaram os conteúdos da dança. O espaço dado para escolhas fazia com que eles buscassem em referências 
pessoais soluções para o desafio (interessante) que era dançar ideias suas e refletissem sobre seus ações e atitudes.

As observações permitiram não só avaliar a atuação do jogo enquanto recurso didático nos processos criativos em dança, mas perceber que os alunos se sentiam motivados (internamente) a experimentar e explorar as aulas, fato que motiva (extrinsecamente) qualquer professor. Através da ludicidade os alunos se sentiam seguros para explorar movimentos e o desafio de solucionar propostas impulsionava a imaginação.

Os processos criativos não estavam presentes com um peso de obrigação, de imposição. Eles foram construídos coletivamente e existiram para todos, num ambiente envolvente foram possíveis e significativos.

$$
* * *
$$

\section{REFERÊNCIAS}

ALENCAR, Eunice Soriano de; FLEIRTH, Denise de Souza. Criatividade: Múltiplas perspectivas. 3.ed. Brasília: Universidade de Brasília, 2003.

BARBOSA, Ana Mae. Arte/educação contemporânea: Consonâncias internacionais. São Paulo: Cortez, 2005.BARRETO, Débora. Dança...: Ensino, sentidos e possibilidades na escola. 2.ed. Campinas: Autores associados, 2005.

BRASIL. Parâmetros Curriculares Nacionais: Arte. Brasília: MEC/SEF, 1997.

COURTNEY, Richard. Jogo, teatro e pensamento. Traduzido por Karen Astrid Muller e Silvana Garcia. São Paulo: Perspectiva, [2003]. Tradução de Play, drama e thought: The intellectual Background to drama education.

DUARTE JÚNIOR, João Francisco. Por que arte-educação? 6.ed. Campinas: Papirus, 1991.

FERRAZ, Maria Heloísa C. de T.; FUSARI, Maria F. de Rezende e. Metodologia do ensino de arte. 2.ed. São Paulo: Cortez, 1999.

GREINER, Christine. O Corpo. 3.ed. São Paulo: Annablume, 2008.

HUIZINGA, Johan. Homo ludens. São Paulo: Perspectiva, 2000. 
MATURANA, Humberto R.; VERDEN-ZÖLLER, Gerda. Amar e brincar: Fundamentos esquecidos do humano. São Paulo: Palas Athena, 2004.

OSTROWER, Fayga. Acasos e criação artística. 2.ed. Rio de Janeiro: Campus, 1999.

RYNGAERT, Jean-Pierre. Jogar, representar: práticas dramáticas e formação. São Paulo: Cosac Naify, 2009.

ROOYACKERS, Paul. 101 more dance games for children: New fun and creativity with movement. Alameda: Hunter House, 2003.

SPOLIN, Viola. Jogos teatrais: Um fichário de Viola Spolin. 2.ed. Perspectiva: São Paulo, 2006.

STRAZZACAPPA, Márcia. A educação e a fábrica de corpos: A dança na escola. Cad. CEDES, Abr 2001, vol. 21, n. 53, p. 69-83. ISSN 0101-3262. Disponível em <http:// www.scielo.br/scielo.php> Acesso em: 25 jun. 2008.

VYGOTSKY, L. A formação social da mente. São Paulo: Martins Fontes, 1989.

Recebido em agosto de 2018.

Aprovado em outubro de 2018. Publicado em dezembro de 2018. 